\title{
Anatomic Stage IA Breast Cancer AJCC v8
}

National Cancer Institute

\section{Source}

National Cancer Institute. Anatomic Stage IA Breast Cancer A/CC v8. NCI Thesaurus. Code C139536.

Stage IA includes: T1, N0, M0. T1: Tumor measuring $20 \mathrm{~mm}$ or less in greatest dimension. N0: No regional lymph node metastasis is identified or isolated tumor cell clusters (ITCS) are identified only. MO: No clinical or radiographic evidence of distant metastases. Imaging studies are not required to assign the M0 category. (AJCC 8th ed.) 